\title{
MELACAK ETIKA PROTESTAN DALAM MASYARAKAT MUSLIM INDONESIA
}

Oleh:

Sun Choirol Ummah

Sunchoirolummah@uny.ac.id

Universitas Negeri Yogyakarta

\begin{abstract}
Abstrak
Etika Protestan mendasarkan pada tradisi penyelamatan dari aliran Calvinisme. Paham yang dipelopori oleh Yohanes Calvin ini menekankan bahwa segala kehidupan di dunia merupakan pengabdian terhadap Tuhan. Kaum Calvinis mengajarkan kepada pengikutnya untuk gigih dalam menggapai kejayaan hidup di dunia. Hal itu hanya akan dapat diwujudkan dengan spirit dan etos kerja keras. Bila seseorang menginginkan kehidupan akhirnya bahagia, maka harus berupaya untuk memperbanyak harta. Islam sebagai agama yang sangat lengkap mengatur tata kehidupan pemeluknya juga memberikan arahan menjalankan kehidupan ekonominya. Harta bukanlah tujuan, ia hanya sekedar alat untuk menumpuk pahala demi tercapainya falah (kebahagiaan dunia dan akhirat). Empat prinsip utama dalam sistem ekonomi yang diisyaratkan dalam Alquran yakni hidup hemat dan tidak bermewah-mewahan, pengimplementasian zakat, penghapusan riba, dan menjalankan usaha-usaha yang halal.
\end{abstract}

Kata kunci: etos kerja, ibadah, ekonomi Islam.

\begin{abstract}
Protestant ethics is based on the salvation tradition of Calvinism. This notion pioneered by John Calvin emphasizes that all life in the world is devotion to God. Calvinists teach their followers to be persistent in achieving the glory of life in the world. It will only be realized by the spirit and ethos of hard work. If someone wants life to finally be happy, then they must try to increase their wealth. Islam as a religion that is very complete governs the life of its adherents also provides direction to run its economic life. Property is not a goal, it is only a tool to accumulate merit for the achievement of falah (happiness of the world and the hereafter). The four main principles in the economic system that are implied in the Qur'an are living frugally and not being extravagant, implementing zakat, abolishing usury, and running halal businesses.
\end{abstract}

Keywords: work ethic, worship, Islamic economy.

\section{PENDAHULUAN}

Dalam konteks transformasi sosial, agama diyakini memiliki peran penting dalam membangun ruang kesadaran dan perilaku ekonomi.
Transformasi ajaran agama dalam masyarakat bisa dikatakan sebagai proses memahami wahyu. Dalam hubungan antara pemeluk agama dengan pemahaman agamanya dalam kenyataan 
sering dijumpai keberagamaan umat dengan kesalehan individu seringkali berbanding terbalik dengan etos kerja dan semangat membangun kemandirian ekonomi. Hal ini banyak dijumpai dalam berbagai problem sosial ekonomi yang terjadi di masyarakat justeru dari tingkat religiositas yang tinggi ini.

Dengan melacak kembali pemikiran Max Weber tentang etika Protestan, penulis mencoba melihat kaitan agama Islam dengan ekonomi di Indonesia, apakah Islam telah gagal menjadi alat transformasi sosial ekonomi atau memang masyarakat memiliki pemahaman tersendiri atas perilaku ekonomi sehingga pemahaman keberagamaan kerap dianggap terpisah dengan problem sosial mereka seharihari? Bagaimana ajaran agama Islam tentang sosial ekonomi dimaknai dan diaktualisasikan?

\section{PEMBAHASAN}

\section{Ukuran Kemiskinan}

Kemiskinan merupakan fenomena sosial klasik yang sudah melekat dalam masyarakat. Ukuran dan pengertiannya bersifat relatif, bergantung pada kondisi sosial ekonomi masyarakat tersebut. Ukuran seperti ini tentulah berbeda antara satu negara dengan negara lainnya. Bank dunia menetapkan ukuran penduduk miskin bila memiliki penghasilan sekitar \$2 per hari sedangkan rata-rata masyarakat paling miskin memiliki pendapatan dalam kisaran \$5 atau Rp. 50.000,- per hari.

Keseragaman pemerintah dalam memaknai kemiskinan secara statistik baik secara regional maupun nasional membuat upaya mengatasi kemiskinan sering tidak tepat sasaran. Selain itu, pemaknaan atas kemiskinan yang dilakukan pemerintah hanya dalam perspektif ekonomi semata membuat pengertian kemiskinan menjadi kabur, bahwa dalam faktanya kemiskinan juga terjadi dalam hal sosio budaya dan mentalitas. Secara administratif bisa dipahami bahwa langkah pemerintah sudah sesuai dengan prosedur. Misalnya survey BPS yang mendata dan menetapkan ukuran, tidak menutup kemungkinan seseorang bisa merasa miskin bila melihat perbandingan dengan sekitarnya yang memiliki harta berlebih.

Lewis dalam karyanya Five Families Studies in the Culture of Poverty (1959), mengemukakan bahwa orientasi nilai, pola hidup, dan cara berpikir orang miskin mencerminkan suatu kebudayaan kemiskinan. Tesis utamanya adalah bahwa orang miskin memiliki karakteristik dan nilai-nilai 
budaya yang berbeda dengan orang kebanyakan dan membentuk sub-kultur tersendiri. Lewis berpandangan bahwa kemiskinan bukan semata bersumber pada kebijakan negara yang didominasi golongan elit yang melahirkan ketimpangan ekonomi atau kebijakan pemerintah yang tak adil sehingga membuahkan marginalisasi sosial. Karakteristik kebudayaan kemiskinan antara lain, rendahnya semangat dan dorongan untuk meraih kemajuan, lemahnya daya juang mengubah kehidupan, rendahnya motivasi bekerja keras, tingginya tingkat kepasrahan (fatalistik), respons yang pasif dalam menghadapi kesulitan ekonomi, lemahnya aspirasi untuk membangun kehidupan yang lebih baik, cenderung mencari kepuasan sesaat dan berorientasi masa sekarang (present time orientation), dan tidak berminat pada pendidikan formal yang berdimensi masa depan (Lewis,Oscar, 1959: 13).

Bila dilihat dari konteks agama sebenarnya jauh lebih jelas. Dalam Islam dibedakan secara tegas antara mereka yang disebut sebagai ‘fakir’ dan 'miskin’ kendatipun mereka yang miskin adakalanya fakir atau sebaliknya. Orang miskin adalah mereka yang tidak atau kurang memiliki potensi untuk memenuhi kebutuhan primer dalam kehidupannya, sementara orang fakir adalah mereka yang memiliki potensi yang belum direalisasikan untuk mencukupi kebutuhan hidup sehari-hari.

Di India misalnya, negara yang memiliki agama mayoritas Hindu, membagi masyarakatnya menjadi empat kasta. Brahmana, menduduki kasta yang paling tinggi, kemudian diteruskan deengan kasta Ksatria, Waisya, dan Sudra (rakyat jelata), sedangkan masyarakat yang tidak berkasta dan dianggap paling miskin yakni golongan Paria.

Masyarakat agraris (Jawa) mengacu pada kepemimpinan, mengenal pelapisan-pelapisan dalam masyarakat. Lapisan terbawah adalah rakyat banyak atau disebut juga dengan wong cilik bukan pegawai. Golongan ini biasanya diisi oleh para petani, pedagang, dan para buruh, serta beberapa tukang. Sedangkan lapisan atas yang bisa langsung menyangga kedudukan raja adalah kaum priyayi (para yayi dan kerabat raja). Priyayi sendiri digolongkan dalam berbagai lapisan kepangkatan atau jarak keluarga dengan raja (Ishomuddin, 2005: 212-213).

Clifford Geertz seorang Indonesianis yang mencoba memetakan stratifikasi masyarakat Jawa lewat penelitiannya di Mojokuto. Dalam 
bukunya The Religion in Java, ia mengelompokkan orang Jawa menjadi tiga kelas, abangan, santri, dan priyayi. Geertz menggambarkan abangan sebagai kelompok masyarakat yang menitikberatkan segi-segi sinkretisme Jawa yang menyeluruh dan secara luas berhubungan dengan unsur-unsur petani di antara penduduk. Sementara santri sebagai kelompok masyarakat yang mewakili sikap yang menitikberatkan pada segi-segi Islam dan sinkretisme. Pada umumnya berhubungan dengan elemen dagang maupun elemen-elemen tertentu di antara para petani. Sedangkan priyayi digambarkan sebagai kelompok masyarakat yang menitikberatkan pada segi-segi individu dan berhubungan dengan unsur-unsur birokrasi (Geerz, Clifford, 1981: 8).

Hasil temuan Geertz ini dibantah keras oleh Koentjoroningrat yang mengatakan istilah abangan dan santri telah menunjuk dua varian religius dalam kebudayaan Jawa karena menurutnya istilah priyayi tidak bisa dijadikan rujukan religius apapun juga. Para priyayi bisa tergolong sebagai santri ataupun abangan karena mereka mungkin beragama Kristen, Islam, atau Hindu. Senada dengan Koentjoroningrat, Ruth R. McVey juga berpendapat bahwa masyarakat Jawa hanya terdiri dari santri dan abangan. Alasan ini didasarkan pada pemikiran pra-Islam yang mewakili kebudayaan desa dan keraton di Jawa pedalaman (Zaini Muchtarom, 1988: 9).

Sementara dalam ranah akademis terdapat banyak pengertian normatif tentang kemiskinan, mulai dari sekedar ketidakmampuan memenuhi kebutuhan konsumsi dasar dan memperbaiki keadaan (kemiskinan konsumtif), kurangnya kesempatan berusaha hingga pengertian yang lebih luas yang memasukkan aspek sosial dan moral. Ada lagi yang mengatakan bahwa kemiskinan terkait dengan sikap, budaya hidup, dan lingkungan dalam suatu masyarakat, atau kemiskinan merupakan bentuk ketakberdayaan sekelompok masyarakat terhadap sistem yang diterapkan oleh pemerintah sehingga mereka berada pada posisi yang sangat lemah dan tereksploitasi (kemiskinan struktural). Tetapi pada umumnya ketika orang berbicara tentang kemiskinan yang dimaksud yakni kemiskinan material.

Ukuran kemiskinan kadangkala dicermati dari sistem pelapisan dalam masyarakat (stratifikasi sosial). Dalam stratifikasi sosial terdapat beberapa hal yang menjadi dasar dalam menentukan seseorang berada dalam stratifikasi yang mana. Ridwan (2012) memaparkan ada 
empat hal yang bisa dijadikan sebagai dasar dalam menentukan stratifikasi sosial, pertama, ukuran kekayaan atau ekonomi, barangsiapa memiliki kekayaan paling banyak maka ia akan termasuk lapisan teratas dalam sistem pelapisan sosial. Kekayaan tersebut dapat dilihat pada bentuk tempat tinggal, benda-benda tersier yang dimiliki, cara berpakaian, maupun kebiasaannya dalam berbelanja. Kedua, ukuran kekuasaan dan wewenang (politik), seseorang yang memiliki kekuasaan atau wewenang yang paling besar akan memempati lapisan teratas. Ukuran ini sering tidak lepas dari ukuran kekayaan karena kekayaan dapat menguasai yang tidak kaya atau sebaliknya, kekuasaan dapat mendatangkan kekayaan.

Ketiga, ukuran kehormatan (sistem nilai). Ukuran ini tidak terlepas dari kekayaan dan kekuasaan. Orang yang disegani akan menempati lapisan atas dalam masyarakat. Biasanya ini sangat terasa ada masyarakat tradisional yang menghormati orang yang banyak jasanya, orang tua atau orang yang berbudi luhur. Keempat, ukuran ilmu pengetahuan termasuk kecakapan dan keterampilan. Ukuran ini biasa digunakan dalam masyarakat yang menghargai ilmu pengetahuan. Penguasaan ilmu pengetahuan biasanya tergambar dalam gelar-gelar akademik ataupun profesi. Kondisi berbeda bila gelar yang disandang lebih dinilai tinggi daripada ilmu pengetahuan yang disandangnya sehingga banyak orang yang berusaha dengan cara-cara yang tidak benar untuk memperoleh gelar kesarjanaan, misalnya dengan membeli skripsi, menyuap, ijazah palsu, dan seterusnya (Muhtadi Ridwan, 2012: 13).

Pendapat di atas merupakan suatu penggambaran bahwa stratifikasi sosial sebagai gejala yang universal, artinya dalam setiap masyarakat bagaimana pun juga keberadaannya pasti akan didapatkan pelapisan sosial tersebut. Paul B. Horton (1989) mengatakan bahwa dua ribu tahun yang lalu Aristoteles mengemukakan berdasarkan tingkat ekonomi, penduduk dapat dibagi ke dalam tiga golongan, yaitu golongan sangat kaya, golongan sangat miskin, dan golongan yang berada di antara keduanya. Terdiri atas golongan proletariat, golongan kapitalis (borjuis) dan golongan menengah (borjuis rendah) (Horton, Paul B., 1989: 4). Karl Marx berpendapat bahwa kelas sosial utama Aristoteles dan Karl Marx menyadari hal itu, kriteria jenis kekayaan dan juga profesi pekerjaan merupakan kriteria yang sederhana, sekaligus menyatakan bahwa dalam masyarakat selanjutnya 
menuju masyarakat yang semakin modern dan kompleks, stratifikasi sosial yang terjadi dalam masyarakat akan semakin banyak.

Dari berbagai pengertian tentang stratifikasi di atas paling tidak ada tiga pengertian stratifikasi sosial. Golongan pertama mendefinisikan bahwa masyarakat terdiri dari kelas atas (upper class) dan kelas bawah (lower class). Sementara golongan kedua terdiri dari tiga kelas yaitu kelas atas (upper class), kelas menengah (middle class), dan kelas bawah (lower class). Golongan yang ketiga memaknai stratifikasi masyarakat dalam kelas atas (upper class), kelas menengah (middle class), kelas menengah ke bawah (lower middle class), dan kelas bawah (lower class).

\section{Pemahaman Agama terhadap}

\section{Masyarakat Miskin}

Pola pemahaman agama masyarakat miskin amat beragam. Hal tersebut diakibatkan faktor pendidikan (formal dan non formal) yang berbeda, lingkungan dan pergaulan serta faktor historis perkembangan masyarakat itu sendiri. Pemahaman agama terbentuk melalui proses perjalanan kehidupan bermasyarakat yang panjang dan dinamis sesuai dengan ruang dan waktu serta interaksi sosial masyarakat.
Keberadaan mushalla, masjid, pesantren, serta berbagai jenis kegiatan keagamaan yang diadakan hampir setiap malam seusai mereka bekerja merupakan bukti yang menunjukkan motivasi kuat masyarakat untuk terus melestarikan dan menambah pengetahuan agama mereka. Institusi pendidikan ini sebagaimana yang diungkapkan Talcott Parson dalam teori struktural fungsional memberikan pengaruh yang kuat bagi kehidupan masyarakat dan pandangannya terhadap nilai-nilai agama yang mendasari seluruh aspek kehidupan mereka.

Agama masyarakat memiliki pengaruh yang kuat dalam membentuk perilaku sosial ekonomi. Namun pemahaman agama semata tidak selalu berhasil mengejawantahkan apa yang dipahami dengan apa yang harus dipraktikkan. Tindakan sosial dan ekonomi masyarakat juga dipengaruhi oleh faktor-faktor lain di luar nilai-nilai agama. Hal inilah yang melahirkan kenyataan ada sebagian masyarakat yang memiliki pengetahuan agama yang dianggap baik (dilihat dari kualitas pendidikan dan lingkungan keluarga) namun justru tidak berhasil menerapkan nilai-nilai agama dalam kehidupannya. Sebaliknya ada sebagian masyarakat yang memiliki pengetahuan agama awam namun perilaku sosial 
ekonominya persis dengan apa yang diajarkan dalam nilai-nilai agama. Hal ini juga berlangsung dalam konteks etos kerja, hubungan kerja, interaksi dengan masyarakat, dan perilaku sosial lain.

Saad menyatakan sebab-sebab terjadinya kemiskinan terkait dengan model interaksi antara manusia dengan dirinya sendiri, dengan sesamanya, dengan alam, dan dengan masyarakatnya (Muhtadi Ridwan, 2012: 43-44). Sebabsebab kemiskinan yang berkaitan dengan kondisi alam terjadi bila dilakukan pola destruktif antara manusia dan alam seperti eksploitasi alam tanpa melakukan analisis dampak lingkungan, kecenderungan untuk menghabiskan seluruh potensi alam, keengganan mengadakan peremajaan demi kelanjutan alam, dan sebagainya. Akibat lebih lanjut dari pola interaksi demikian yakni terjadinya kemiskinan baik secara langsung maupun tidak, baik generasi yang sedang eksis maupun generasi selanjutnya. Di sisi lain kondisi alam yang gersang dan tidak memiliki potensi yang bisa dikembangkan juga merupakan cobaan yang diberikan Tuhan kepada umat manusia sebagaimana yang dilukiskan Alquran dalam surat al-Baqarah ayat 155.

Sedang sebab-sebab kemiskinan yang berkaitan dengan kondisi manusia itu sendiri disebabkan kurangnya kepercayaan pada kemampuan mereka, keengganan mengaktualisasikan potensi yang ada dalam bentuk kerja nyata yang serius, serta keengganan memberikan respek optimal terhadap perputaran waktu. Sedang salah satu sebab kemiskinan yang berkaitan dengan kondisi sosial diataranya terkonsentrasinya modal di tangan orang-orang kaya (konglomerat) yang menyebabkan orang-orang fakir tidak memiliki kesempatan untuk mengaktualisasikan potensi-potensinya demi meraih prestasi di bidang ekonomi. Problemnya, posisi umat Islam di Indonesia yang mayoritas, betapa besar peran yang dilakukan dalam membangun perekonomian, bila ditinjau dari aspek aktivitas yang dilakukan. Namun yang menjadi tidak wajar adalah jumlah yang besar itu menyandang predikat yang kurang mengembirakan yaitu "kemiskinan dan ketidakteraturan dalam manajemen.” Hal ini ditunjukkan banyaknya kaum santri yang diidentikkan dengan kaum miskin dan tidak mengetahui bagaimana cara mengelola aktivitas perekonomian. 
Perubahan Sosial Ekonomi Masyarakat Muslim Indonesia

Para sosiolog umumnya meyakini bahwa perubahan sosial adalah gejala sosial yang sangat wajar dan merupakan ciri utama masyarakat. Dinamika masyarakat yang terus bergerak dalam rangka menemukan sesuatu yang baru (inovasi). Sebagai gejala wajar maka hampir tidak ada masyarakat yang tidak berubah. Masyarakat yang mengalami intensitas perubahan sosial merupakan masyarakat yang memiliki dinamika interaksi sosial yang cukup tinggi, demikian pula sebaliknya.

Kingsley Davis menyatakan bahwa perubahan sosial adalah perubahanperubahan yang terjadi dalam struktur dan fungsi masyarakat. Misalnya timbul pengorganisasian buruh dalam masyarakat kapitalisme telah menyebabkan perubahan-perubahan dalam hubungan antara buruh dengan majikan dan seterusnya. Gillin menyatakan bahwa perubahanperubahan sosial adalah suatu variasi dari cara hidup yang telah diterima, baik karena perubahan-perubahan kondisi georafis, kebudayaan, material, komposisi penduduk, ideologi maupun karena adanya difusi ataupun penemuanpenemuan baru dalam masyarakat. Soekanto (2000) memerinci faktor internal yang mendorong perubahan sosial ke dalam beberapa hal seperti sistem pendidikan, toleransi atas penyimpangan perilaku, keterbukaan kelas-kelas sosial, kemajemukan masyarakat, ketidakpuasan masyarakat, orientasi masa depan dan nilai sosial untuk berubah ke arah lebih baik (Soerjono Soekanto, 2000: 361-365). Lebih lanjut Soekanto menjelaskan bahwa perubahan sosial lazimnya dilakukan melalui saluran-saluran perubahan sosial (channel of change). Saluran tersebut berfungsi agar suatu perubahan dikenal, diterima, diketahui, serta digunakan oleh masyarakat yang dalam bahasa sosiologi proses ini disebut sebagai institutialization. Salah satu perubahan yang dimaksud di atas yakni lembaga agama (Soerjono Soekanto, 2000: 369-370). Artinya dalam konteks perubahan sosial, institusi agama merupakan salah satu saluran sekaligus agen perubahan sosial.

Max Weber mengamati aliran Calvinisme yang menekankan pada tradisi penyelamatan bahwa segala kehidupan di dunia merupakan pengabdian terhadap Tuhan. Kaum Calvinis mengajarkan kepada pengikutnya untuk gigih dalam menggapai kejayaan hidup di dunia. Dan hal itu hanya akan bisa diwujudkan 
dengan spirit dan etos kerja keras. Gerakan etik keagamaan rasional ini mengajarkan bahwa kesuksesan hidup di dunia merupakan tolok ukur bahwa ia sebagai manusia terpilih. Menurut Calvinis kerja keras adalah panggilan hidup yang bernilai ibadah (Muhtadi Ridwan, 2012: 55). Di samping itu, Weber juga menganalisis bahwa perubahan masyarakat Barat menuju kemajuan ekonomi tidak hanya disebabkan oleh kelompok bisnis dan pemodal. Dalam penelitiannya sebagian dari nilai keberagamaan Protestan memiliki aspek rasionalitas ekonomi yang nilai-nilainya dirujukkan pada spirit keagamaan. Semangat membangun kemandirian ekonomi secara individual dari doktrin-doktrin tersebut telah ikut membangun peradaban kapitalisme awal secara massif, padahal semangat etik ini bukan sebuah gerakan sistemik dan terorganisir yang memunculkan Protestanisme dan Calvinisme dengan doktrinnya yang menekankan sikap puritan dan asketis memungkinkan terrjadinya perubahan struktur ekonomi yang mendasar (Muhtadi Ridwan, 2012: 54-55).

Perubahan pada sistem dan sikap keberagamaan itu menurut Weber telah menyebabkan banyak orang bisa keluar dari lilitan kemiskinan. Doktrin
Protestanisme dan Calvinisme itu bertitik tolak dari prinsip yang menempatkan manusia sebagai “petugas” Tuhan yang harus mengelola harta benda Tuhan di dunia ini seefisien dan seefektif mungkin dan karena itu manusia harus bekerja keras, disiplin, dan hemat atau tidak boros. Weber juga mengemukakan bahwa perilaku ekonomi berupa etos kerja, kedisiplinan, dan tidak konsumtif, merupakan faktor determinan dalam pertumbuhan dan perkembangan ekonomi. Perilaku ekonomi yang positif akan mendorong terbukanya kesempatan kerja dan penataan ekonomi yang lebih baik. Kalangan pengusaha progressif merupakan perintis keberdayaan ekonomi masyarakat.

Dalam konteks masyarakat Muslim, penelitian Clifford Geertz yang diterjemahkan dalam Penjaja dan Raja: Perubahan Sosial dan Modernisasi Ekonomi di Dua Kota di Indonesia (1977) bisa dijadikan satu rujukan lainnya. Dalam salah satu riset di Kediri Jawa Timur pada sekitar 1960an, Geertz menemukan banyak pengusaha di kota kecil tersebut yang berafiliasi pada organisasi Islam Modernis. Mereka adalah kaum santri yang sangat taat menjalankan ibadah. Istilah santri memang lazim digunakan oleh kalangan muslim yang memiliki keberagamaan 
lebih dalam. Santri biasanya dilekatkan pada anak didik atau lulusan pesantren yang memiliki wawasan Islam di atas orang kebanyakan. Kacamata Geertz santri menjadi salah satu kategori sosial yang secara antropologis berbeda dengan kategori abangan dan priyayi. Disamping itu, dalam bekerja mereka memiliki tingkat kedisiplinan yang tinggi, senantiasa bekerja keras, hemat atau jauh dari perilaku konsumtif.

Di tempat berbeda, di Kotagede Yogyakarta, antropolog Jepang Mitsuo Nakamura seperti dalam karyanya Bulan Sabit Muncul dari Balik Pohon Beringin (1983) juga mendapatkan temuan yang nyaris sama dengan Geertz. Penemuan di akhir 1970an yang dilakukannya memberikan informasi bahwa orangorang kaya di Kota Gede kebanyakan adalah kaum santri yang memiliki keberagamaan yang taat. Dan dalam konteks perilaku ekonomi, mereka pun memiliki etos kerja wiraswastawan yang tinggi dan dilekatkan dengan afiliasi mereka pada Islam modernis. Sementara itu Hiroko Horikoshi dalam karyanya Kiai dan Perubahan Sosial (1987) yang melakukan riset di Garut, Jawa Barat pada 1970-an memberikan informasi yang relatif sama. Horikoshi menemukan geliat ekonomi di kalangan pengusaha pribumi yang rata-rata terlahir dari keluarga pesantren. Mereka merupakan keturunan kiai yang memiliki tingkat keberagamaan yang taat sekaligus menjadi aktor-aktor ekonomi. Kebetulan hampir semuanya terlibat dan berpartisispasi dalam organisasi Islam modernis. Perilaku ekonomi kalangan anak kiai ini memiliki watak disiplin, memiliki etos kerja kuat, dan cenderung tidak boros.

Meski memberikan ilustrasi yang mengaitkan antar keberagamaan Islam modernis dengan keberdayaan ekonomi, tiga antropolog di atas memang belum bisa membuktikan tesis Weber tentang hubungan agama (Islam) dengan etos kerja dan perilaku ekonomi masyarakat Indonesia. Adalah Muhammad Sobary yang menemukan titik terang tesis Weber tetang etika Protestan di masyarakat muslim di Indonesia. Dalam bukunya yang berjudul Etika Islam: Dari Kesalehan Individual Menuju Kesalehan Sosial (2007), Sobary melihat adanya etos kerja dan gerakan wirausaha yang bangkit dari kesadaran keberagamaan masyarakat di Suralaya Jawa Barat. Penelitian Sobary tersebut membuktikan bahwa tesis Weber tidak sepenuhnya bisa diterima "apa adanya." Tesis Weber mengambil penelitian pada pengusaha menengah dan atas yang mempunyai konstruksi pemikiran yang 
maju karena didukung basis pendidikan yang cukup. Penelitian ini melengkapi kajian Clifford Geertz di Mojokuto, James T. Siegel di Aceh, dan Lance Castle di Jawa (santri). Ketiga peneliti ini juga berasumsi spirit keagamaan (Islam) berpengaruh pada spirit berwirausaha. Ketiganya juga menjelaskan bahwa ternyata mereka 'gagal' bersaing dengan korporasi dagang yang dibangun oleh Cina. Terbukti hingga sekarang kantongkantong perdagangan besar di Indonesia banyak dikuasai oleh warga keturunan Cina. Meski demikian Sobary memberikan catatan bahwa penelitiannya di Suralaya memang tidak bisa mendapatkan spirit keberagamaan, dalam konteks ekonomi mandiri, sedahsyat apa yang ditemukan Weber di Eropa Barat. Sobary mendapatkan perilaku ekonomi masyarakat muslim di Suralaya tidak bisa mewujud seperti spirit Protestan di Barat menjadi ideologi besar yang melahirkan pengusaha kelas elite bahkan menguasai struktur ekonomi dunia. Sobary mengemukakan empat alasan tesis Weber tidak berjalan di kalangan masyarakat muslim Suralaya, di antaranya, pertama, keterbatasan ruang sehingga pemasaran terbatas, kedua, tidak menjadi gerakan ekonomi yang massif hanya bersifat personal, ketiga, spirit keagamaan warga Suralaya tidak sekuat sebagai 'panggilan' kaum Calvinis Protestan, berdagang hanya untuk kewajiban kebutuhan keluarga, keempat, mereka mempunyai cukup modal dan pengetahuan tentang pengembangan usaha.

Pengkajian terhadap teori Weber yang dilakukan untuk menguji tesisnya yang mengatakan Islam adalah agama yang anti akal sehingga tidak dapat bersikap rasional dalam menjalankan ekonomi (Taufik Abdullah, 1982: 25). Kemudian dengan pandangan sinis Weber mengatakan bahwa Islam merupakan agama perang yang telah menciptakan patrimoniallisme (Turner, Briyan S., 1974: 8). Struktur patrimonial yang terdapat dalam masyarakat Islam yang berlandaskan atas 'kharisma' penguasa yang mengakibatkan Islam kurang mendukung semangat kapitalisme. Weber menyatakan bahwa tidak mungkin spirit of capitalism muncul dari etika Islam. Dengan lebih tegas Weber mengatakan "kapitalisme memerlukan situasi yang bebas, hal ini diakibatkan oleh sistem yang bertolak dari pertukaran tenaga dan upah dari orang-orang yang bebas. Persyaratan rohaniah bagi kapitalisme juga tidak dimiliki ajaran Islam yaitu 
kecenderungan rasional (Turner, Briyan S., 1974: 12-13).

Namun Maxime Rodinson tidak sepenuhnya setuju dengan pendapat ini. Ia mengatakan bahwa dalam Islam, rasionalitas memainkan peranan penting yang di dalamnya Allah terus menerus mengharuskan manusia untuk mengadakan penalaran (Rodinson, Maxime, 1974: 76). Hal ini dibuktikan dengan tidak kurang dari 50 kali Alquran menggunakan kata kerja 'aqala yang berarti akal atau menghubungkan pikiran-pikiran atau suatu pemahaman dari suatu alasan intelektual (AlMaqdisi, Faidullah al-Husni, tt: 306). Lebih lanjut Rodinson mengatakan bahwa etika yang diajarkan oleh Alquran juga tidak jauh berbeda dengan yang disebut Weber sebagai 'etika Protestan' yaitu jujur, kerja keras, dan hemat (Rodinson, Maxime, 1974: 76). Dengan demikian sebenarnya agama Islam dalam hal bekerja memiliki makna yang sama dengan Calvinis Protestan yang mendorong semangat kapitalisme. Secara jelas dapat dilihat dari penelitian Irwan Abdullah dalam disertasinya yang berjudul The Muslim Bussinessmen of Jatinom: Religious Reform and Economic Modernization in a Central Javanese Town (1994), memiliki bukti lain yang dapat dikatakan otentik, bahwa para pengusaha kecil (pedagang) seperti yang terjadi di Jatinom, Klaten Jawa Tengah, mereka penganut Islam modernis yang berhasil menerjemahan paham keagamaannya menjadi paham keagamaan yang reformis sehingga sangat mendorong bagi terciptanya kesuksesan usaha yang mereka jalankan.

Sifat-sifat khas Protestan (ulet, kerja keras, disiplin) sebagaimana klaim Weber tersebut di atas juga telah ditentukan dalam etika Islam. Konsep calling misalnya juga terdapat dalam ajaran Islam. Seseorang yang berhasil dalam kehidupan dunia dinyatakan sebagai orang yang diberkati Tuhan. Selanjutnya usaha lebih giat juga merupakan perbuatan yang diutamakan dalam Islam dan hal ini dinyatakan dalam konsep akhirat (Ajat Sudrajat, 1994: 112).

Sementara itu, Sukidi dalam tulisannya di harian Kompas (2005) mengetengahkan pembahasan tentang Etika Protestan Muslim Puritan Muhammadiyah sebagai Reformasi Islam Model Protestan. Studi Clifford Geertz yang mengetengahkan tentang etos kerja dan perilaku ekonomi kaum reformis puritan dalam konteks masyarakat muslim bisa dijadikan satu rujukan lainnya. Dalam penelitiannya di Mojokuto tersebut Geertz menemukan 
banyak pengusaha di kota kecil tersebut yang berafiliasi pada organisasi Islam modernis. Mereka adalah kaum santri yang sangat taat menjalankan ibadah. Di samping itu dalam bekerja mereka memiliki tingkat kedisiplinan yang tinggi, senantiasa bekerja keras, hemat atau jauh dari perilaku konsumtif. Menurut Geertz perilaku ekonomi ini dipengaruhi dengan pemahaman kalangan santri modernis ini terhadap ajaran Islam. Ahmad Janan berkomentar bahwa kemajuan ekonomi efektif di Mojokuto bergerak dari ekonomi pasar dan aliran perdagangan seluruhnya terpecah menjadi sejumlah besar transaksi kecil antarpribadi yang saling berhubungan menuju ekonomi perusahaan (Ahmad Janan Asifudin, 2004: 161). Benar apa yang dikemukakan Asyifudin yang menyatakan bahwa ajaran dan aqidah Islam berpotensi besar untuk menjadi sumber motivasi etos kerja Islami yang tinggi yaitu dapat menjadi sumber motivasi intrinsik yang mantap. Motivasi inilah yang nantiya menjadi modal untuk menggairahkan aktivitas ekonomi dan bisnis. Hal ini juga ditemukan oleh Jonge (1984) dalam mengkaji Perkembangan Ekonomi dan Islamisasi di Madura. Dalam penelitiannya ternyata kiai mendorong aktivitas ekonomi pedagang dan membela mereka bila tindakan mereka menjengkelkan orang.

Begitu pula penelitian di Kudus Kulon yang dilakukan Mu'tasim dan Mulkan (1998) di lingkungan pengikut Tarekat Sadhaliyah yang menemukan bahwa berkat tarekatlah mereka bisa berhasil dalam berusaha. Mereka dapat bekerja dengan baik tanpa rasa takut dan was-was dan selalu ingat untuk meminta pertolongan kepada Allah. Mereka percaya sepenuhnya bahwa nasib mereka berada di tangan Allah dan keberkahan guru (Murshid) telah menjadikan pengikut tarekat memiliki semangat bekerja keras dan sikap penuh percaya diri (Muhtadi Ridwan, 2012: 98-99).

Uraian di atas menunjukkan bahwa keberhasilan ekonomi dalam berbagai bentuk aktivitasnya seperti halnya dalam usaha dagang dan aktivitas ekonomi lainnya tidak selamanya ditentukan oleh faktor-faktor ekonomi semata, tetapi lebih banyak ditentukan pula oleh faktor non ekonomi seperti nilai moral agama dan budaya.

Perilaku ekonomi dasar biasanya dijalankan melalui konsep produksi, konsumsi dan distribusi, dan redistribusi. Islam sebagai agama yang sangat lengkap mengatur tata kehidupan pemeluknya juga memberikan arahan 
menjalankan kehidupan ekonominya. Di antara ayat-ayat Alquran yang berkaitan dengan kegiatan produksi antara lain surat al-Baqarah (2): 22, 29, al-Nahl (16): 5, 11, 65-67, Luqman (31): 20, alMulk (67): 15. Ayat tersebut memberikan penjelasan adanya upaya memenuhi kebutuhan dalam konteks kemaslahatan, tidak menimbulkan kerusakan lingkungan. Adapun ayat yang mengandung ajaran tentang konsumsi misalnya surat al-Baqarah (2): 168, al-Isra (17): 26-28, al-Nahl (16): 114. Dalam ayat tersebut tergantung prinsip halal dan baik, tidak diperkenankannya perilaku berlebihlebihan pelit, boros, harus seimbang, proporsional, dan pertanggungjawaban. Demikian pula ayat-ayat yang berkaitan dengan distribusi, seperti surat al-Anfal (8): 1, al-Hasyr (59): 7, al-Hadid (57) :7, al-Taubah (9): 60 mengandung nilai larangan keras penumpukan harta benda atau barang kebutuhan pokok. Pola distribusi harus mendahulukan aspek prioritas berdasarkan need assessment.

Pemahaman terhadap ayat-ayat kunci di atas diharapkan mencapai pemahaman yang proporsional. Khusus terkait dengan konsumsi setidaknya terdapat empat prinsip utama dalam sistem ekonomi yang diisyaratkan dalam Alquran. Pertama, hidup hemat dan tidak bermewah-mewahan (abstain from wasteful and luxurius living) yang bermakna tindakan ekonomi diperuntukkan hanya sekedar pemenuhan kebutuhan hidup (needs) bukan pemuasan keinginan (wants). Kedua, implementasi zakat (implentation of zakat) dan mekanismenya pada tataran negara merupakan obligatory zakat system bukan voluntary zakat system. Selain zakat terdapat pula instrumen sejenis yang bersifat sukarela (voluntary) yaitu infak, sadaqah, wakaf, dan hadiah. Ketiga, penghapusan riba (prohibition of riba) menjadikan sistem bagi hasil (profit-loss sharing) dengan instrumen mudarabah dan musyarakah sebagai pengganti sistem kredit termasuk bunga (interest rate). Keempat, menjalankan usaha-usaha yang halal (permissible conduct) jauh dari maisir dan garar meliputi bahan baku, proses produksi, manajemen, output produksi, hingga proses distribusi dan konsumsi harus dalam kerangka halal (Muhtadi Ridwan, 2012: 101-102).

Dari empat prinsip tersebut terlihat model perilaku ekonomi yang sesuai dengan ajaran Islam. Dalam menyikapi harta harta bukanlah tujuan, ia hanya sekedar alat untuk menumpuk pahala demi tercapainya falah (kebahagiaan dunia dan akhirat). 


\section{SIMPULAN}

Islam di antara agama-agama di dunia adalah satu-satunya agama yang menjunjung tinggi nilai kerja. Ketika masyarakat di dunia umumnya menempatkan kelas pendeta dan militer di tempat yang tinggi, Islam menghargai orang-orang yang berilmu, petani, pedagang, tukang, dan pengrajin. Penghargaan Islam terhadap kerja tercermin juga dalam sistem kepemilikan. Apa yang ada di langit dan di bumi adalah milik Allah. Tetapi kesemuanya itu merupakan sumber rezeki yang terbuka bagi manusia yang mengolah dan memperdagangkannya. Sesungguhnya agama memperhatikan pola perilaku kehidupan ekonomi pemeluknya. Arti yang lain, terdapat kaitan yang erat antara pemahaman agama seseorang dengan pola perilaku ekonomi yang dijalani dalam kehidupan, tidak terkecuali dalam masyarakat Muslim Indonesia. Selain itu, belakangan di berbagai negara Islam mulai dikembangkan berbagai konsepkonsep baru tentang ekonomi Islam. Spirit ini menurut beberapa kalangan merupakan satu semangat baru dalam memompa pemberdayaan ekonomi dengan menempatkan spirit ajaran keagamaan untuk mendorong kesadaran akan kemandirian ekonomi. Meski lebih berada pada institusionalisasi, namun konsep ekonomi syariah yang belakangan mengemuka kembali adalah salah satu contoh upaya baru dalam mengembangkan ekonomi yang disemangati oleh nilai-nilai etik keagamaan.

\section{UCAPAN TERIMA KASIH}

Penulis mengucapkan terima kasih kepada Redaksi Jurnal Humanika atas dimuatnya artikel ini.

\section{DAFTAR PUSTAKA}

Ahmad Janan Asifudin. (2004). Etos Kerja Islami. Surakarta: Universitas Muhammadiyah.

Ajat Sudrajat. (1994). Etika Protestan dan Kapitalisme Barat, Relevansinya dengan Islam Indonesia, Jakarta: Bumi Aksara.

Al-Maqdisi, Faidullah al-Husni. (tt). Fath al-Rahman li Talibi Ayat alQur'an. Surabaya: Maktabah Dahlan.

Geertz, Clifford. (1977). Penjaja dan Raja: Perubahan Sosial dan Modernisasi Ekonomi di Dua Kota di Indonesia. Jakarta: Buku Obor.

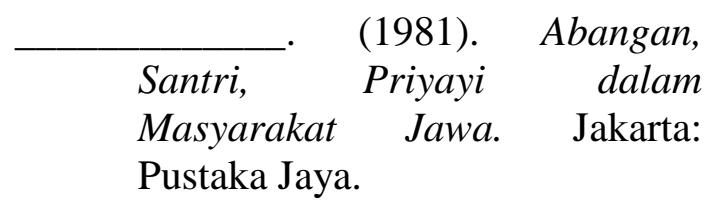

Horikoshi, Hiroko. (1987) Kiai dan Perubahan Sosial. Jakarta: P3M.

Horton, Paul B. Dan Chester L. Hunt. (1989). Sosiologi. terj. 
Aminuddin Ram, Jakarta: Erlangga.

Irwan Abdullah. (1994). "The Muslim Bussinessmen of Jatinom: Religious Reform and Economic Modernization in a Central Javanese Town." Disertation. Amsterdam: University of Ansterdam.

Ishomuddin. (2005). Sosiologi Perspektif Islam. Malang: UMM.

Lewis,Oscar. (1959). Five Families:

Mexican Case Studie in the Culture of Poverty. New York: Basic Books, Inc.

Muhammad Sobary. (2007). Etika Islam:

Dari Kesalehan Individual

Menuju Kesalehan Sosial.

Yogyakarta: LKiS.

Muhtadi Ridwan. (2012). Geliat Ekonomi Islam, Memangkas Kemiskinan Mendorong Perubahan. Malang: UIN Maliki Press.
Nakamura, Mitsuo. (1983). Bulan Sabit Muncul dari Balik Pohon Beringin. Yogyakarta: Gajahmada University Press.

Rodinson, Maxime. (1974). Islam and Capitalism. Harmondsworth: Penguin Books.

Soerjono Soekanto. (2000). Sosiologi Suatu Pengantar. Jakarta: Raja Grafindo Persada.

Sukidi. (2005). “Etika Protestan Muslim Puritan Muhammadiyah sebagai Reformasi Islam Model Protestan”, Kompas, Bentara, Rabu, 01 Juni.

Taufik Abdullah (ed.). (1982). Agama, Etos Kerja, dan Perkembangan Ekonomi. Jakarta: LP3ES.

Turner, Briyan S. Weber and Islam: A Critic Study, London and Boston: Routledge \& Keagen Paul, 1974.

Zaini Muchtarom. (1988). Santri dan Abangan di Jawa. Jakarta: INIS. 